\title{
AFLATOXIN B1 DETOXIFICATION BY CELL-FREE EXTRACTS OF RHODOCOCCUS STRAINS
}

\author{
ANITA RISA $^{1}$, DALMA MAJA DIVINYI ${ }^{1}$, ERZSÉBET BAKA ${ }^{2}$ and \\ CSILLA KRIFATON $^{1 *}$ \\ ${ }^{1}$ Department of Environmental Safety and Ecotoxicology, Faculty of Agricultural and \\ Environmental Sciences, Szent István University, Gödöllő, Hungary \\ ${ }^{2}$ Department of Applied and Environmental Microbiology, Research Institute of \\ Agro-Environmental Sciences, National Agricultural Research and Innovation Centre, \\ Budapest, Hungary
}

(Received: 4 May 2017; accepted: 21 June 2017)

\begin{abstract}
Aflatoxin B1 (AFB1) produced by Aspergillus molds is a genotoxic and carcinogenic mycotoxin. For the elimination of mycotoxins from food and feed, biodetoxification can be a successful tool. The aim of this study was to reveal biodetoxification with the cell-free extracts of Rhodococcus erythropolis NI1 and Rhodococcus rhodochrous NI2, which have been already proved to detoxify AFB1. Extracellular matrices of cultures and also intracellular extracts were applied for detoxification. In both cases, media containing constitutively produced and AFB1induced enzymes were tested, respectively. The $\mathrm{pH}$ tolerance of enzymes in the detoxification was examined at $\mathrm{pH} 7,7.5$, and 8 . The remained genotoxicity was detected by SOS-Chromotest and the AFB1 concentration was measured by high performance liquid chromatography with fluorescence detection. In the extracellular matrix, no reduction of genotoxicity was observed. However, detoxification was completed by intracellular enzymes. In intracellular extracts of both strains, genotoxicity was ceased by the constitutive enzymes within $6 \mathrm{~h}$ but induced and constitutive enzymes collectively achieved this result within minutes. Moreover, total biodetoxification was observed at every $\mathrm{pH}$ adjustment. Analytical results confirmed $>84 \%$ degradation potential in each sample. Our results indicate a uniquely fast way for the detoxification of AFB1 with intracellular enzymes of R. erythropolis NI1 and $R$. rhodochrous NI2.
\end{abstract}

Keywords: aflatoxin B1, biodetoxification, genotoxicity, intracellular extracts

*Corresponding author; E-mail: krifaton.csilla@mkk.szie.hu 


\section{Introduction}

Aflatoxin B1 (AFB1) is one of the most harmful mycotoxins occurring almost worldwide. Aflatoxins are a group of several compounds mainly produced by Aspergillus flavus and Aspergillus parasiticus [1] but more other Aspergillus strains (Aspergillus pseudotamarii, Aspergillus nomius, Aspergillus bombycis, Aspergillus parvisclerotigenus, Aspergillus minisclerotigenes, and Aspergillus arachidicola) have been proved to be aflatoxin producers [2]. Due to the appearance of these toxigenic molds on cereals, seeds, and spices, AFB1 endangers both animals and humans.

All among natural aflatoxins, AFB1 is one of the most toxic compounds and also proved to be human carcinogenic compound; according to IARC classification, AFB1 belongs to Group 1 [3]. Due to high liposolubility, AFB1 can easily get into the bloodstream and reach organs especially the liver. During its metabolism, AFB1 can be transformed into less or more harmful metabolites such as AFM1, AFP1, AFQ1, and aflatoxicol [4]. AFB1 is metabolized in humans by cytochrome P450 enzymes, which transform it to aflatoxin B1-8,9-epoxide (aflatoxin B1-2,3oxide). This compound is highly reactive and forms DNA adducts. Binding to DNA, AFB1 is proved to damage DNA and cause liver cancer [5, 6]. Besides carcinogenicity, it has genotoxic and mutagenic effect; moreover, AFB1 is teratogenic, induces disorders in the reproductive system and has immunosuppressive effect additionally [7, 8].

Mycotoxins can be eliminated from feed- and food stuff using adsorbents or biotransforming agents. Since adsorbing materials can bind nutrients and vitamins, biotransformation can be an appropriate way for this purpose [9]. During the toxin degradation, which is completed by bacteria, fungi, or their enzymes, harmful breakdown products may be produced. For that reason, not only the biological effect of the parent toxin needs to be monitored but also its metabolites during biodegradation processes.

The structure of aflatoxins is made up of a coumarin ring, which compound is utilized by several microorganisms. Biodegradation experiments were carried out by Ciegler et al. [10], where Aspergillus niger strains and Penicillium raistrickii NRRL 2038 transformed AFB1 into other fluorescent breakdown products. Similarly, AFB1 was converted into aflatoxicol by Dactylium dendroides, Mucor alternans, Mucor griseocyanus, Absidia repens, Helminthosporium sativum [11], Rhizopus spp. [12, 13], A. niger, a non-aflatoxin producer $A$. flavus, Eurotium herbariorum [13] and into aflatoxin R0 by A. niger, Mucor ambiguus, Trichoderma viride [14]. Working with cell-free extracts of eukaryote strains, Cheng and $\mathrm{Gu}$ [15] and Liu et al. [16] reported a multienzyme called 
aflatoxin-detoxifizyme (ADTZ), which was extracted from mycelia of Armillariella tabescens. This enzyme could degrade AFB1 and was identified as an oxidase and renamed to aflatoxin-oxidase (AFO) later [17]. Motomura et al. [18] extracted an extracellular enzyme from Pleurotus ostreatus, which could reduce the amount of the toxin. Laccase enzymes of $P$. ostreatus, Peniophora sp. were produced and used for biodegradation of AFB1 by Alberts et al. [19]. The filtrates of the fungal culture could degrade approx. $36 \%$ and $40 \%$ of the compound, but the degradation rate increased up to more than $80 \%$; moreover, the mutagenicity was ceased using pure laccase enzyme from Trametes versicolor. After the transformation of the gene encoding the laccase production into A. niger, the AFB1 degradation rate was $55 \%$. Pure laccase enzyme from $T$. versicolor was applied for the detoxification of AFB1 by Zeinvand-Lorestani et al. [20] as well, and 67\% toxin was removed from the medium with a remarkable loss of mutagenicity during 2 days. Not only laccase but manganese peroxidase produced by $P$. ostreatus has been proved to have detoxification ability as well, with $90 \%$ elimination of AFB1 after $48 \mathrm{~h}[21]$.

Ciegler et al. [10] examined the AFB1-transforming ability of prokaryotes, and one of the analyzed strains, Flavobacterium aurantiacum NRRL B-184 could reduce the concentration of AFB1; moreover, no toxicity of the metabolites was detected by Duckling assay. Arai et al. [22] tested strains, which were able to grow in the presence of AFB1. Besides the examination of the antimicrobial effect of the toxin, Nocardia asteroides IFM8 proved to transform the mother toxin to another fluorescent metabolite. Later on, biodegradation of AFB1 was proved by Corynebacterium rubrum [14], Mycobacterium fluoranthenivorans [23], Bacillus licheniformis, and Bacillus subtilis [24-26], Brevundimonas spp., Klebsiella spp., Enterobacter spp., Brachybacterium spp., Cellulosimicrobium spp. [27], Rhodococcus spp. [28], Pseudomonas putida strains [29], and Streptomyces spp. $[28,30]$; moreover, some members of the Streptomyces genus could decrease or cease the genotoxicity of AFB1 proved by SOS-Chromotest according to Harkai et al. [30]. During recent years, cell-free extracts of bacteria were applied for biodegradation and biodetoxification as well. The culture supernatant of Stenotrophomonas maltophilia 35-3 [27], B. subtilis ANSB060 [25], and a Pseudomonas aeruginosa strain [31] eliminated more than $80 \%$ of AFB1. The biodegradation ability of Rhodococcus erythropolis DSM 14303 strain was examined by Teniola et al. [32], where living cells and cell-free extracts were analyzed and compared to two Nocardia corynebacterioides and M. fluoranthenivorans sp. nov. DSM $44556^{\mathrm{T}}$. Intracellular extracts of the Rhodococcus and Mycobacterium strains seemed to be more effective than the two Nocardia strains. One year later, Alberts et al. [33] examined the extracellular supernatant of 
$R$. erythropolis DSM 14303, and the biodegradation ability of induced and constitutively produced enzymes was also analyzed. The extracellular enzymes, which were produced constitutively, could degrade more than $70 \%$ of the toxin and greatly reduced the genotoxicity. Zhao et al. [34] purified an extracellular enzyme and named myxobacteria aflatoxin degradation enzyme (MADE) from Myxococcus fulvus ANSM068, which could degrade aflatoxins effectively. Recently, AFB1 degradation by a supernatant of a B. licheniformis strain was carried out by Raksha Rao et al. [35].

In our laboratory, biodetoxification potential of Rhodococcus strains was examined further. According to the results of Krifaton et al. [36], 5 rhodococci could detoxify $2 \mu \mathrm{g} \mathrm{mL} \mathrm{mL}^{-1}$ AFB1 confirmed by SOS-Chromotest. These strains were $R$. erythropolis NI1 and GD2B, Rhodococcus rhodochrous NI2 and ATCC 12674, Rhodococcus pyridinivorans K405. Further examinations were carried out by Cserháti et al. [37] with the aim of biodetoxification of mycotoxins by Rhodococcus strains. Biodetoxification potential of additional strains of $R$. pyridinivorans, $R$. erythropolis, $R$. rhodochrous, and $R$. globerulus was analyzed resulting in total loss of genotoxic effect.

In this study, two Rhodococcus strains ( $R$. erythropolis NI1 and $R$. rhodochrous NI2) were applied, which have already proved to detoxify AFB1 [36]. Our purpose was to reveal biodegradation of AFB1 by cell-free extracts of the strains. In these experiments, biodetoxification potentials of intra- and extracellular enzymes; moreover, induced and constitutively produced enzymes were compared. Further experiments were also carried out to investigate the $\mathrm{pH}$ tolerance of revealed enzymes. The success of the biodetoxification was checked by different methods. The remained toxin concentration was evaluated by high performance liquid chromatography with fluorescence detection (HPLC-FLD) (Wessling Hungary Ltd., Hungary) and remained genotoxic effect in the extracts was examined by SOS-Chromotest (Environmental Bio-detection Products Inc., Ontario, Canada).

\section{Materials and Methods}

\section{Applied bacterial strains and AFB1 stock solution}

For the AFB1 degradation experiments, cell-free extracts of two bacterial strains were used, which cells have been proved to detoxify AFB1 [36]. These strains, namely $R$. erythropolis NI1 and $R$. rhodochrous NI2, have been isolated from a hydrocarbon-contaminated site in Hungary and have been placed into a private culture collection. The toxin was purchased from Fermentek Ltd. (Israel) and dissolved in acetone. 
Different set-ups were carried out to reveal extra- or intracellular enzymes, which are responsible for the AFB1 degradation. Strains maintained at $-80{ }^{\circ} \mathrm{C}$ were streaked on Luria-Bertani (LB) agar plates $(10 \mathrm{~g}$ triptone, $5 \mathrm{~g}$ yeast extract, $10 \mathrm{~g} \mathrm{NaCl}$, and $18 \mathrm{~g}$ bacteriological agar dissolved in $1 \mathrm{~L}$ distilled water) and incubated at $28{ }^{\circ} \mathrm{C}$. Single colonies of both strains were inoculated into fresh LB medium $(20 \mathrm{~mL})$ and incubated for 3 days $\left(28^{\circ} \mathrm{C}\right)$. $10 \mathrm{~mL}$ pre-cultures were further inoculated into $90 \mathrm{~mL} \mathrm{LB}$ medium and also cultured for 3 days. After the incubation, bacterial cultures were centrifuged at $4,000 \mathrm{rpm}$ for $20 \mathrm{~min}$ at $4{ }^{\circ} \mathrm{C}$ (Eppendorf $5810 \mathrm{R}$ Centrifuge, Eppendorf, Germany) and supernatants were filtered $(0.2 \mu \mathrm{m})$ avoiding growth of remained cells. In this matrix, only extracellular enzymes were presented. To obtain the intracellular enzymes, after centrifugation of the culture $\left(4{ }^{\circ} \mathrm{C}, 4,000 \mathrm{rpm}, 20\right.$ min), supernatants were decanted. Cells were washed twice with phosphate buffer (67 mM, pH 7), and resuspended in the buffer ( $1 \mathrm{~g}$ pellet in $3 \mathrm{~mL}$ buffer). Bacterial cells were disintegrated by ultrasonic cell disintegrator (Branson Digital Sonifier, Emerson Industrial Automation, Minnesota, USA) with the help of zircon powder for $6 \times 1 \mathrm{~min}$ in pulsed mode avoiding temperature increase. Cell debris and supernatant were separated by centrifugation and supernatant was filtered $(0.2 \mu \mathrm{m})$.

Biodegradation experiments were carried out in $1.5 \mathrm{~mL}$ Eppendorf tubes, where untreated supernatants and supernatants of the sonicated cells were contaminated with AFB1 reaching $1 \mu \mathrm{g} \mathrm{mL}^{-1}$ final concentration, whereas LB medium and phosphate buffer contaminated by AFB1 (in $1 \mu \mathrm{g} \mathrm{mL}{ }^{-1}$ final concentration) were used as controls. The biodegradation experiment was incubated for $6 \mathrm{~h}$ at $37^{\circ} \mathrm{C}$ in the dark. An amount of $100 \mu \mathrm{L}$ samples were removed from tubes at zero time and end point and samples were stored at $-20{ }^{\circ} \mathrm{C}$ until further testing. Moreover, preincubation was needed to induce the production of biodegradative enzymes; therefore, strains were grown in the presence of AFB1 for 3 days before harvesting. Hereupon extra- and intracellular enzymes were obtained as mentioned earlier.

To prove whether the biodetoxification process occurred enzymatically or not, proteinase $\mathrm{K}$ plus sodium dodecyl sulfate (SDS) treatment was applied. Proteinase $\mathrm{K}$ is a protease isolated from Tritirachium album, which is able to hydrolyze keratin and has strong proteolytic activity on several proteins [38]. This feature makes it applicable to digest revealed enzymes. After preparation of cellfree extracts, $1 \mathrm{mg} \mathrm{mL}^{-1}$ proteinase $\mathrm{K}$ plus $1 \%$ SDS was added to the matrices and they were incubated for $1 \mathrm{~h}$ at $37^{\circ} \mathrm{C}$. After incubation, the matrices were contaminated by AFB1 (in final concentration of $1 \mu \mathrm{g} \mathrm{mL} L^{-1}$ ) and incubated for 
six more hours at $37^{\circ} \mathrm{C}$ in dark. Experiments were carried out in three replicates and each of them was set up in triplicate.

Investigation the $\mathrm{pH}$ tolerance of enzymes

The $\mathrm{pH}$ tolerance of enzymatic reactions was investigated, thus experiments were carried out at $\mathrm{pH} 7,7.5$, and 8, after the disintegration of cells according to the section "Preparing cell-free extracts and AFB1 biodetoxification" and incubated at $37{ }^{\circ} \mathrm{C}$ for $6 \mathrm{~h}$ in the dark in each test.

\section{Determination of protein concentration}

Protein concentrations in media were determined according to Bradford [39]. Briefly, the assay is based on the ability of Coomassie Brilliant Blue G-250 dye to bind proteins and change the absorption maximum of the dye from 465 to $595 \mathrm{~nm}$. The protein-dye complex, which becomes blue, can be measured by spectrophotometer at $595 \mathrm{~nm}$. In the assay, bovine serum albumin (BSA) was used as a standard protein, and diluted with phosphate buffer in concentrations of 0.025 , $0.125,0.250,0.500,0.750,1.000,1.500$, and $2.000 \mathrm{mg} \mathrm{mL}^{-1}$; subsequently $100 \mu \mathrm{L}$ of controls and samples were mixed with $1 \mathrm{~mL}$ Coomassie reagent (SigmaAldrich Co., Missouri, USA). After $2 \mathrm{~min}$, while the dye bonds to proteins, the absorbance was measured by UV-VIS spectrophotometer (Genesys 10 UV-VIS, Thermo Fisher Scientific Inc., Massachusetts, USA). Absorbance values of BSA were plotted on a graph and a standard curve was applied to estimate the protein concentration of extracts.

\section{Detection of the genotoxicity}

The remained genotoxicity was detected by SOS-Chromotest purchased from Environmental Bio-Detection Products Inc. (Ontario, Canada). Briefly, the test is based on the operon fusion of the $s f i A$ gene, which expression induces the SOS-repair mechanism and the lacZ gene also encoding the $\beta$-galactosidase production. The test organism is Escherichia coli PQ37, in which lacZ region has been inserted under control of SOS-repair region. Genotoxic compound induces the expression $s f A$ gene and $l a c Z$ gene together producing $\beta$-galactosidase [40]. In this colorimetric assay, $\beta$-galactosidase can be transformed into a product resulting in blue color development with the addition of X-gal (Blue Chromogen) substrate. Besides the genotoxicity, detecting cytotoxic effect is a control 
measurement in this test. Alkaline phosphatase activity is indicative of the viability of the test organism. After the addition of p-nitrophenyl phosphate substrate, yellow color development can be observed.

First of all, the lyophilized E. coli $\mathrm{PQ} 37$ was rehydrated, and $10 \mathrm{~mL}$ fresh casitone broth medium ( $2.5 \mathrm{~g}$ yeast extract, $2.5 \mathrm{~g}$ casein peptone, and $8.5 \mathrm{~g} \mathrm{NaCl}$ dissolved in $1 \mathrm{~L}$ distilled water) were inoculated by $20 \mu \mathrm{L}$ rehydrated strain and incubated overnight at $37^{\circ} \mathrm{C}$ in the dark. The test was carried out in 96-well microplate, where $10 \mu \mathrm{L}$ samples were added into the wells in triplicate. As positive controls $\mathrm{AFB} 1,2$-amino-anthracene (2AA) and 4-nitroquinoline 1-oxide (4NQO) were used. Measuring extracellular enzymes, LB was used as negative control, but in the case of intracellular enzymes, phosphate buffer was used as negative control. Samples and indirect genotoxins (AFB1, 2AA) were metabolically activated by $\mathrm{S} 9 \mathrm{mix}$ including rat liver extracts treated with genotoxic compounds earlier, but $4 \mathrm{NQO}$ was measured without metabolic activation. The optical density of the test strain was adjusted to $\mathrm{OD}_{600}=0.05$, and $100 \mu \mathrm{L}$ bacterial suspension with or without $\mathrm{S} 9 \mathrm{mix}$ was added onto samples and controls. The microplate was incubated in the dark at $37{ }^{\circ} \mathrm{C}$ for $2 \mathrm{~h}$ and then the substrate was added. The substrate containing $50 \mathrm{mg}$ p-nitrophenyl phosphate dissolved in $10 \mathrm{~mL}$ Blue Chromogen and $100 \mu \mathrm{L}$ of the mixture was added to samples; afterward, the microplate was incubated further for one and a half hours at $37^{\circ} \mathrm{C}$. The absorbance was measured in a microplate reader (ELx800 Absorbance Reader, BioTek Instruments, Vermont, USA), where blue color was detected at $620 \mathrm{~nm}$, and yellow color was detected at $405 \mathrm{~nm}$. From the absorbance values of triplicate samples, induction factor (IF) was determined according to the equation reported by Legault et al. [41]. If IF value is lower than 1.5, there is no detectable genotoxic effect. The IF can be determined according to Equation (1).

$$
\mathrm{IF}=\left(C_{405} \times S_{620}\right) /\left(S_{405} \times C_{620}\right),
$$

where $C$ is the absorbance value of the negative control, $S$ is the absorbance value of the sample measured at different wavelengths (405 and $620 \mathrm{~nm}$ ).

\section{Analytical measurement}

The analytical detection was carried out by an accredited laboratory (Wessling Hungary Ltd., Hungary) and the remained AFB1 concentration was detected by HPLC-FLD. After ultrasonic homogenization, the pre-column derivatization was accomplished at $55{ }^{\circ} \mathrm{C}$ for $15 \mathrm{~min}$ with the mixture of trifluoroacetic acid:acetic acid:distilled water $(1: 1: 8)$. For the measurement, 
Agilent 1100 High-Performance-Liquid-Chromatograph (Agilent Technologies, California, USA) was used and equipped with Restek C18 (150 $\mathrm{mm} \times 4.6 \mathrm{~mm} \times$ $5 \mu \mathrm{m}$ ) column (Restek Corporation, Pennsylvania, USA). The detection was completed by fluorescent detector at the wavelengths of 365 (extinction) and $440 \mathrm{~nm}$ (emission). Depending on the AFB1 concentration, 200 or $10 \mu \mathrm{L}$ sample were mixed with 800 or $990 \mu \mathrm{L}$ water:acetonitrile:methanol (68:16:16) eluent agent. An amount of $100 \mu \mathrm{L}$ of the mixture was injected into the equipment under isocratic conditions. The retention time was $17 \mathrm{~min}$ and the applied column temperature was $30{ }^{\circ} \mathrm{C}$. As a standard, Supelco Aflatoxin Mix Kit (Supelco Inc., Pennsylvania, USA) was used.

\section{Statistical analysis}

For statistical analysis, data were analyzed by Microsoft Excel (Microsoft Office, Microsoft Inc., Washington, USA) and GraphPad Prism (GraphPad Inc., California, USA). After confirmation of normal distribution, one-sample $t$-test was applied. The analysis was carried out to confirm significant differences from the non-genotoxic threshold $\mathrm{IF}=1.5$. Differences were considered significant if $p<0.05$.

\section{Results}

In this research, cell-free extracts of two Rhodococcus strains (NI1 and NI2) were analyzed according to their AFB1-detoxifying ability. Different set-ups were carried out to reveal what sorts of enzymes play the key role in the degradation processes. The detoxification potentials of induced and constitutively produced enzymes, furthermore extra- and intracellular enzymes were compared.

\section{Protein concentrations}

After obtaining cell-free extracts, relative protein concentrations of each extract were determined according to defined concentrations of the control (BSA). Protein concentrations of extracellular extracts of applied strains were less than the lowest standard concentration, i.e., $<0.025 \mathrm{mg} \mathrm{mL}^{-1}$. However, concentrations of constitutive and induced intracellular enzymes were evaluated. Determined protein concentrations of intracellular extracts are listed in Table I, where values are means of triplicate samples supplemented by standard deviations. Comparing the concentration of constitutive and induced enzymes of both strains, negligible 
Table I. Protein concentration of the intracellular extracts of Rhodococcus erythropolis NI1 and R. rhodochrous NI2

\begin{tabular}{lcc}
\hline & \multicolumn{2}{c}{ Intracellular extracts } \\
\cline { 2 - 3 } Protein concentration & Constitutive proteins $\left(\mathrm{mg} \mathrm{mL}^{-1}\right)$ & Induced proteins $\left(\mathrm{mg} \mathrm{mL}^{-1}\right)$ \\
\hline$R$. erythropolis NI1 & $6.09 \pm 0.29$ & $6.52 \pm 0.50$ \\
$R$. rhodochrous NI2 & $5.95 \pm 0.34$ & $5.88 \pm 0.98$ \\
\hline
\end{tabular}

Note: The values are mean values supplemented by standard deviations.

differences were observed. The relative protein concentrations were approx. $6 \mathrm{mg} \mathrm{mL}^{-1}$ in each intracellular extract.

\section{Results of the SOS-Chromotest}

The genotoxicity of extracts was measured in the zero time and end point by SOS-Chromotest, and IF are listed in Table II. Samples with IF significantly less than $1.5(p<0.05)$ were considered as non-genotoxic. Extracellular extracts were tested at $\mathrm{pH} \mathrm{7,} \mathrm{and} \mathrm{intracellular} \mathrm{extracts} \mathrm{were} \mathrm{examined} \mathrm{at} \mathrm{pH} 7,7.5$, and 8 .

Evaluating the detoxification ability, neither constitutive nor induced extracellular enzymes of NI1 and NI2 seem to be able to decrease the genotoxicity of the toxin during $6 \mathrm{~h}$. IFs varied between 2.49 and 2.95, which are not significantly less $(p>0.05)$ than the control values (average IF $=2.61$ ). In contrast, intracellular extracts of both strains have remarkable detoxification ability. In the intracellular extracts, genotoxicity was ceased in $6 \mathrm{~h}$ but the rapidity of the degradation processes was different. In cases of constitutive and induced enzymes of NI2 and constitutive enzymes of NI1, outstanding reduction of harmful effect occurred after a few minutes, and no genotoxic effects could be detected at the end of the sixth hours. Induced enzymes of NI1 are needed to be emphasized since total detoxification was detected immediately after enzymes contacted to the toxin (IF $=1.19, p=0.0027)$.

Examining $\mathrm{pH}$ tolerance of the extracts, enzymes were shown to be stable against $\mathrm{pH}$ variations. At $\mathrm{pH} 7.5$, induced enzymes of NI1 and NI2 resulted in immediate detoxifications, IFs are 1.39 in both cases (NI1: $p=0.0202$; NI2: $p=0.0089$ ), and constitutive enzymes were able to cease the genotoxicity during $6 \mathrm{~h}$ (NI1: $p=0.0001 ; \mathrm{NI} 2: p=0.0175)$. At $\mathrm{pH} 8$, only in the induced extract of NI1 reached detoxification immediately ( $\mathrm{IF}=1.40, p=0.0065$ ). In every set-up, the enzymatic detoxification was completed within $6 \mathrm{~h}$ at $\mathrm{pH} 8$.

Between $\mathrm{pH} 7$ and 8, the genotoxic effect was ceased by the cell-free extracts in $6 \mathrm{~h}$, as no genotoxicity was detected at the endpoint at all. However, the 


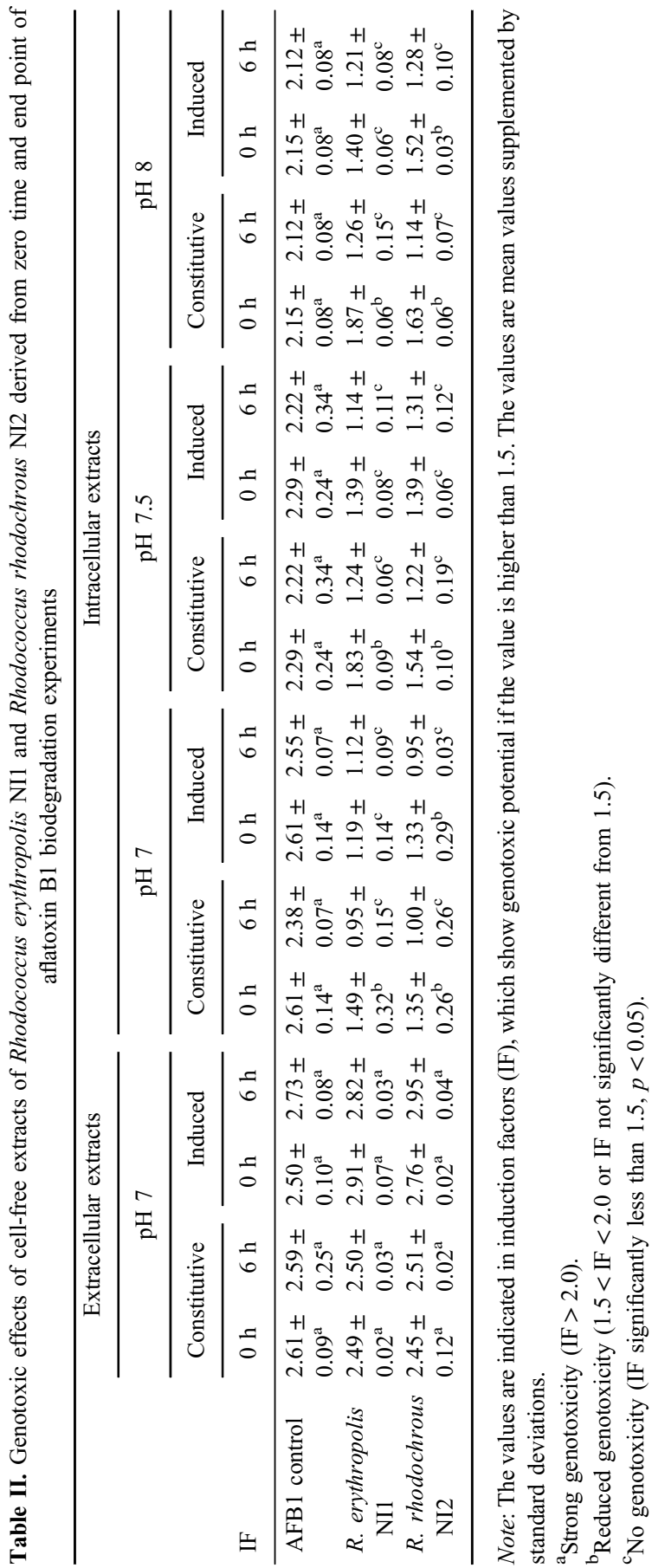


rapidity of the detoxification varied at the different adjustments, but the reduction of genotoxicity at zero points was the most prominent at $\mathrm{pH} 7$.

Analytical results of the AFB1 concentration in the extracts and proteinase K plus SDS-treated extracts

The biodegradation potential of intracellular extracts of strains was evaluated by analytical measurements (Table III). Determination of AFB1 concentration by HPLC-FLD showed more than $80 \%$ biodegradation in the case of all extracts. $84 \%$ degradations were calculated in case of NI2 since there are no differences in the degradation potential of induced and constitutive enzymes. However, constitutively produced enzymes of NI1 resulted in the highest, $91 \%$ degradation potential, which means approx. $0.1 \mu \mathrm{g} \mathrm{mL} \mathrm{m}^{-1}$ AFB1 remained concentration in the extract. Since the preincubated extracts contain constitutive and induced enzymes as well, cell-free extracts of NI1 proved to have approx. $84 \%$ or more biodegradation ability similarly to NI2.

To prove that the biodetoxification was enzymatic, intracellular extracts were treated by proteinase K plus $1 \%$ SDS. Analytical measurements confirmed negligible AFB1 degradation in case of NI1 and no degradation in case of NI2 when intracellular extracts were treated by proteinase K plus SDS. These results suggested inactivation of enzymes caused the loss of detoxification potential, confirming the enzymatic detoxification of AFB1.

Table III. The remained aflatoxin B1 concentration in the untreated and proteinase K plus SDS-treated intracellular extracts of Rhodococcus erythropolis NI1 and Rhodococcus rhodochrous NI2 after 6-h incubation

\begin{tabular}{lcc}
\hline & $\begin{array}{c}\text { AFB1 concentration } \\
\left.(\mu \mathrm{g} \mathrm{mL})^{-1}\right)\end{array}$ & $\begin{array}{c}\text { Degradation } \\
\text { potential }(\%)\end{array}$ \\
\hline AFB1 control & $1.043 \pm 0.04$ & - \\
Constitutive, intracellular extract of $R$. erythropolis NI1 & $0.096 \pm 0.01$ & 91 \\
Induced, intracellular extract of $R$. erythropolis NI1 & $0.169 \pm 0.01$ & 84 \\
Constitutive, intracellular extract of $R$. rhodochrous NI2 & $0.171 \pm 0.01$ & 84 \\
Induced, intracellular extract of $R$. erythropolis NI2 & $0.167 \pm 0.00$ & 84 \\
AFB1 control + proteinase K plus SDS & $0.986 \pm 0.11$ & - \\
Constitutive, intracellular extract of $R$. erythropolis & $0.887 \pm 0.06$ & 0 \\
NI1 + proteinase K plus SDS & & $1.002 \pm 0.15$ \\
Constitutive, intracellular extract of $R$. rhodochrous & & 0 \\
NI2 + proteinase K plus SDS & & \\
\hline
\end{tabular}

Note: The values are determined by high performance liquid chromatography with fluorescence detection. The values are mean values supplemented by standard deviations. 


\section{Discussion}

AFB1 is a naturally occurring carcinogenic compound, which poses a relevant threat to animals and human widespread. Several methods (chemical, physical, and biological) have been developed for the AFB1 elimination [42-44], but the biological detoxification seems to be the most potent way for this purpose. Microorganisms are proved to be able to degrade AFB1 but the enzymes behind these processes are less examined and only a few of them have been identified. Fungal enzymes, isolated from $A$. tabescens, removed $90 \%$ of the toxin and the loss of mutagenicity was proven by Ames test after $48 \mathrm{~h}$ [16]. The multienzyme was named ADTZ, but its oxidative features proved that the enzyme is an oxidase and it has been renamed AFO later [17]. From a bacterial strain, namely M. fulvus, an extracellular enzyme has been purified, identified, and named MADE. After $48 \mathrm{~h}$ the enzyme effectively removed aflatoxins (AFB1, AFG1, and AFM1) from the supernatant, but the reduction of genotoxicity was not evaluated [34].

In this research, cell-free extracts of two microbes $(R$. erythropolis NI1 and $R$. rhodochrous NI2) were used, after the living cells of these strains proved to be able to detoxify AFB1 in our earlier studies [36]. However, these living microorganisms are not allowed to be applied in food- and feed processes according to the Qualified Presumption Safety concept of EFSA [45]. For this reason, cell-free extracts were examined to reveal what sorts of enzymes manage the AFB1 detoxification. Extracellular enzymes in supernatants were tested after harvesting cells. Intracellular enzymes were derived from the bacterial cells using ultrasonic disintegration. Not only constitutively produced enzymes were tested but also preincubation with the presence of AFB1 was applied for the examination of induced enzymes.

Our results suggested that extracellular enzymes do not have detoxification ability based on the genotoxicity determined by SOS-Chromotest. However, intracellular (induced and constitutive) enzymes of both strains were able to complete the detoxification of AFB1. The experiments were carried out at different

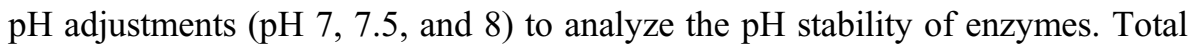
detoxification was observed within $6 \mathrm{~h}$ in every $\mathrm{pH}$ adjustment. Analytical measurements confirmed $84 \%-91 \%$ degradation by intracellular enzymes of NI1 and NI2. Extracts were also treated by proteinase $\mathrm{K}$ plus $1 \%$ SDS before contaminated by AFB1. After digesting enzymes, no reduction of AFB1 concentration was measured, this observation proves that enzymatic biodetoxification occurred. 
The rapidity of AFB1 detoxification in this study is remarkable, compared to data published to date, since AFB1 degradation or detoxification by cell-free extracts of bacteria has been reported in the studies mostly after $72 \mathrm{~h}$. Teniola et al. [32] used the intracellular extract of $R$. erythropolis strain resulting in more than $90 \%$ toxin degradation after $72 \mathrm{~h}$. The extracellular extract of the same $R$. erythropolis strain was examined 1 year later [33], where only $27 \%$ of AFB1 remained and the mutagenic effect was ceased confirmed by Ames test, but only after 72 h. Similarly, extracellular extracts of Stenotrophomonas, Bacillus, and Pseudomonas spp. strains were able to eliminate $80 \%$ AFB1 over $72 \mathrm{~h}[25,27$, 31]. A recent study reported enzymatic AFB1 detoxification, where $90 \%$ of $0.5 \mu \mathrm{g} \mathrm{mL} \mathrm{m}^{-1}$ toxin was removed from the supernatant of $B$. licheniformis CFR 1 after $24 \mathrm{~h} \mathrm{[35].}$

In summary, our results show that the biodetoxification was uniquely fast (less than $6 \mathrm{~h}$ ) applying intracellular extracts of NI1 and NI2. Enzymatic processes were quite stable since the biodetoxification was completed between $\mathrm{pH} 7$ and 8 . Besides the biodegradation of AFB1, the cessation of genotoxicity of the parent toxin and its breakdown products was also proved.

In conclusion, both constitutive and induced intracellular enzymes of $R$. erythropolis NI1 and $R$. rhodochrous NI2 are able to work uniquely fast since the detoxification of AFB1 is completed within $6 \mathrm{~h}$. Consequently, further research is needed to purify and identify enzymes presented in the intracellular extracts of NI1 and NI2. The members of Rhodococcus genus can be applied for biotechnological purposes using only their enzymes according to EFSA QPS list. Since the efficiency of the intracellular extracts of NI1 and NI2 has been confirmed, the application of constitutive intracellular enzymes of both strains is a fast and costeffective way to eliminate mycotoxin contamination. These enzymes presumably may be applicable in feed and food industry in the future.

\section{Acknowledgements}

This research was supported by the Foundation of the Hungarian Society for Microbiology, Research Centre of Excellence (9878-3/2016/FEKUT), and Aquafuture (VKSZ-12-1-2013-0078). The authors thank Balázs Kriszt, József Kukolya, and Mátyás Cserháti.

\section{Conflict of Interest}

The authors declare no conflict of interest. 


\section{References}

1. Diener, U. L., Davis, N. D.: Aflatoxin production by isolates of Aspergillus flavus. Phytopathology 50, 1390-1393 (1966).

2. Varga, J., Frisvad, J., Samson, R.: A reappraisal of fungi producing aflatoxins. World Mycotoxin J 2, 263-277 (2009).

3. WHO-IARC: IARC Monographs on the Evaluation of Carcinogenic Risks to Human. Some Naturally Occurring Substances: Food Items and Constituents, Heterocyclic Aromatic Amines and Mycotoxins. Lyon, France, Vol. 56, p. 599 (1993).

4. Merrill, A. H., Campbell, T. C.: Preliminary study of in vitro aflatoxin B1 metabolism by human liver. Toxicol Appl Pharmacol 213, 210-213 (1974).

5. Wogan, G. N., Edwards, G. S., Newberne, P. M.: Structure-activity relationships in toxicity and carcinogenicity of aflatoxins and analogs. Cancer Res 31, 1936-1942 (1971).

6. Swenson, D. H., Miller, E. C., Miller, J. A.: Aflatoxin B1-2, 3-oxide: Evidence for its formation in rat liver in vivo and by human liver microsomes in vitro. Biochem Biophys Res Commun 60, 1036-1043 (1974).

7. Diapolo, J. A., Elis, J., Erwin, H.: Teratogenic response by hamsters, rats and mice to aflatoxin B1. Nature 215, 638-639 (1967).

8. Raisuddin, S., Singh, K. P., Zaidi, S. I. A., Paul, B. N., Ray, P. K.: Immunosuppressive effects of aflatoxin in growing rats. Mycopathologia 124, 189-194 (1993).

9. EFSA, Boudergue, C., Burel, C., Dragacci, S., Favrot, M., Fremy, J., Massimi, C., Prigent, P., Debognie, P., Pussemier, R. L., Boudra, H., Morgavi, D., Oswald, I., Perez, A., Avantaggiato, G.: Review of mycotoxin-detoxifying agents used as feed additives: Mode of action, efficacy and feed/food safety. EFSA Support Publ 6, 192 (2009).

10. Ciegler, A., Lillehoj, E. B., Peterson, R. E., Hall, H. H.: Microbial detoxification of aflatoxin. Appl Microbiol 14, 934-939 (1966).

11. Detroy, R. W., Hesseltine, C. W.: Transformation of aflatoxin B1 by steroid-hydroxylating fungi. Can J Microbiol 15, 495-500 (1969).

12. Cole, R. J., Kirksey, J. W., Blankenship, B. R.: Conversion of aflatoxin B 1 to isomeric hydroxy compounds by Rhizopus spp. J Agric Food Chem 20, 1100-1102 (1972).

13. Nakazato, M., Morozumi, S., Saito, K., Fujinuma, K., Nishima, T., Kasai, N.: Interconversion of aflatoxin B1 and aflatoxicol by several fungi. Appl Environ Microbiol 56, 14651470 (1990).

14. Mann, R., Rehm, H. J.: Degradation products from aflatoxin B1 by Corynebacterium rubrum, Aspergillus niger, Trichoderma viride and Mucor ambiguus. Eur J Appl Microbiol 2, 297-306 (1976).

15. Cheng, W., Gu, L.: Detoxification of aflatoxin B1 by enzymes isolated from Armillariella tabescens. Food Chem Toxicol 36, 563-574 (1998).

16. Liu, D., Yao, D., Liang, Y., Zhou, T.: Production, purification, and characterization of an intracellular aflatoxin-detoxifizyme from Armillariella tabescens (E-20). Food Chem Toxicol 39, 461-466 (2001).

17. Cao, H., Liu, D., Mo, X., Xie, C., Yao, D.: A fungal enzyme with the ability of aflatoxin B1 conversion: Purification and ESI-MS/MS identification. Microbiol Res 166, 475-483 (2001). 
18. Motomura, M., Toyomasu, T., Mizuno, K., Shinozawa, T.: Purification and characterization of an aflatoxin degradation enzyme from Pleurotus ostreatus. Microbiol Res 158, 237242 (2003).

19. Alberts, J. F., Gelderblom, W. C. A., Botha, A., van Zyl, W. H.: Degradation of aflatoxin B1 by fungal laccase enzymes. Int J Food Microbiol 135, 47-52 (2009).

20. Zeinvand-Lorestani, H., Sabzevari, O., Setayesh, N., Amini, M., Nili-Ahmadabadi, A., Faramarzi, M. A.: Comparative study of in vitro prooxidative properties and genotoxicity induced by aflatoxin B1 and its laccase-mediated detoxification products. Chemosphere 135, 1-6 (2015).

21. Yehia, R. S.: Aflatoxin detoxification by manganese peroxidase purified from Pleurotus ostreatus. Braz J Microbiol 45, 127-133 (2014).

22. Arai, T., Ito, T., Koyama, Y.: Antimicrobial activity of aflatoxins. J Bacteriol 59, 59-64 (1967).

23. Hormisch, D., Brost, I., Kohring, G., Giffhorn, F., Kroppenstedt, R. M., Stackebrandt, E., Färber, P.: Mycobacterium fluoranthenivorans sp. nov., a fluoranthene and aflatoxin B1 degrading bacterium from contaminated soil of a former coal gas plant. Syst Appl Microbiol 27, 653-660 (2004).

24. Petchkongkaew, A., Taillandier, P., Gasaluck, P., Lebrihi, A.: Isolation of Bacillus spp. from Thai fermented soybean (Thua-nao): Screening for aflatoxin B1 and ochratoxin A detoxification. J Appl Microbiol 104, 1495-1502 (2008).

25. Gao, X., Ma, Q., Zhao, L., Lei, Y., Shan, Y., Ji, C.: Isolation of Bacillus subtilis: Screening for aflatoxins B1, M1, and G1 detoxification. Eur Food Res Technol 232, 957-962 (2011).

26. Risan, M. H., Muhsin, A. H.: Efficiency of Bacillus licheniformis to reduce aflatoxin B1 produced by Aspergillus flavus. J Al-Nahrain Univ 18, 108-113 (2015).

27. Guan, S., Ji, C., Zhou, T., Li, J., Ma, Q., Niu, T.: Aflatoxin B 1 degradation by Stenotrophomonas maltophilia and other microbes selected using coumarin medium. Int J Mol Sci 9, 1489-1503 (2008).

28. Eshelli, M., Harvey, L., Edrada-Ebel, R., McNeil, B.: Metabolomics of the biodegradation process of aflatoxin $\mathrm{B} 1$ by actinomycetes at an initial $\mathrm{pH}$ of 6.0 . Toxins 7, 439-456 (2015).

29. Samuel, M. S., Sivaramakrishna, A., Mehta, A.: Degradation and detoxification of aflatoxin B1 by Pseudomonas putida. Int Biodeterior Biodegrad 86, 202-209 (2014).

30. Harkai, P., Szabó, I., Cserháti, M., Krifaton, C., Risa, A., Radó, J., Balázs, A., Berta, K., Kriszt, B.: Biodegradation of aflatoxin-B1 and zearalenone by Streptomyces sp. collection. Int Biodeterior Biodegradation 108, 48-56 (2016).

31. Sangare, L., Zhao, Y., Folly, M. E., Chang, J., Li, J., Selvaraj, J. N., Xing, F., Zhou, L., Wang, Y., Liu, Y.: Aflatoxin B1 degradation by a Pseudomonas strain. Toxins 6, 30283040 (2014).

32. Teniola, O. D., Addo, P. A., Brost, I. M., Färber, P., Jany, K. D., Alberts, J. F., Van Zyl, W. H., Steyn, P. S., Holzapfel, W. H.: Degradation of aflatoxin B1 by cellfree extracts of Rhodococcus erythropolis and Mycobacterium fluoranthenivorans sp. nov. DSM44556T. Int J Food Microbiol 105, 111-117 (2005).

33. Alberts, J. F., Engelbrecht, Y., Steyn, P. S., Holzapfel, W. H., van Zyl, W. H.: Biological degradation of aflatoxin B1 by Rhodococcus erythropolis cultures. Int J Food Microbiol 109, 121-126 (2006). 
34. Zhao, L. H., Guan, S., Gao, X., Ma, Q. G., Lei, Y. P., Bai, X. M., Ji, C.: Preparation, purification and characteristics of an aflatoxin degradation enzyme from Myxococcus fulvus ANSM068. J Appl Microbiol 110, 147-155 (2010).

35. Raksha Rao, K., Vipin, A. V., Hariprasad, P., Anu Appaiah, K. A., Venkateswaran, G.: Biological detoxification of Aflatoxin B1 by Bacillus licheniformis CFR1. Food Control 71, 234-241 (2017).

36. Krifaton, C. S., Kriszt, B., Szoboszlay, S., Cserháti, M., Szücs, Á., Kukolya, J.: Analysis of aflatoxin-B1-degrading microbes by use of a combined toxicity-profiling method. Mutat Res Toxicol Environ Mutagen 726, 1-7 (2011).

37. Cserháti, M., Kriszt, B., Krifaton, C. S., Szoboszlay, S., Háhn, J., Tóth, S., Nagy, I., Kukolya, J.: Mycotoxin-degradation profile of Rhodococcus strains. Int J Food Microbiol 166, 176-185 (2013).

38. Ebeling, W., Hennrich, N., Klockow, M., Metz, H., Orth, H. D., Lang, H.: Proteinase K from the mold Tritirachium album Limber. Eur J Biochem 47, 91-97 (1974).

39. Bradford, M.: A rapid and sensitive method for the quantitation of microgram quantities of protein utilizing the principle of protein-dye binding. Anal Biochem 72, 248-254 (1976).

40. Quillardet, P., Huisman, O., D’Ari, R., Hofnung, M.: SOS chromotest, a direct assay of induction of an SOS function in Escherichia coli K-12 to measure genotoxicity. Proc Natl Acad Sci USA 79, 5971-5975 (1982).

41. Legault, R., Blaise, C., Rokosh, D., Chong-Kit, R.: Comparative assessment of the SOS Chromotest kit and the Mutatox test with the Salmonella plate incorporation (Ames test) and fluctuation tests for screening genotoxic agents. Environ Toxicol Water Qual 9, 45-57 (1994).

42. Méndez-Albores, A., Arámbula-Villa, G., Loarca-Piña, M. G. F., Castaño-Tostado, E., Moreno-Martínez, E.: Safety and efficacy evaluation of aqueous citric acid to degrade B-aflatoxins in maize. Food Chem Toxicol 43, 233-238 (2005).

43. Vekiru, E., Fruhauf, S., Rodrigues, I., Ottner, F., Krska, R., Schatzmayr, G., Ledoux, D. R., Rottinghaus, G. E., Bermudez, A. J.: In vitro binding assessment and in vivo efficacy of several adsorbents against aflatoxin B1. World Mycotoxin J 8, 477-488 (2015).

44. Vosough, P. R., Sani, A. M., Mehraban, M., Karazhyan, R., Karazhyan, R.: In vitro effect of Lactobacillus rhamnosus GG on reduction of aflatoxin B1. Nutr Food Sci 44, 32-40 (2014).

45. EFSA: Introduction of a Qualified Presumption of Safety (QPS) approach for assessment of selected microorganisms referred to EFSA - Opinion of the Scientific Committee. EFSA J 5, 587 (2007). 